\title{
ECONOMICS
}

AND

PHILOSOPHY

Cambridge University Press 


\section{ECONOMICS AND PHILOSOPHY}

\section{Editors}

Daniel M. Hausman

University of Wisconsin, Madison

Michael S. McPherson

Williams College

\section{Editorial Board}

Kenneth J. Arrow, Stanford Unversity; Cristina Bicchier, Carnegie-Mellon Unversity; Mark Blaug, University of London Institute of Education; Robert Cooter, Untversity of Californa, Berkeley; Neil de Marchi, Duke University; Ronald Dworkin, University College, Oxford University and New York University Law School; Jon Elster, University of Oslo and University of Chicago; Frank Hahn, Cambridge University; Jean E. Hampton, Unversity of California, Davis; Albert O. Hirschman, Institute for Advanced Study, Princeton; Edward F. McClennen, Washnington University, Donald N. McCloskey, University of lowaa; Diana Meyers, University of Connecticut; Sidney Morgenbesser, Columbia University; Derek Parfit, All Souls College, Oxford University; Peter Railton, University of Michigan, Ann Arbor; John Roemer, University of California, Davis; Alexander Rosenberg, University of California, Riverstde; Thomas C. Schelling, Harvard University; Frederic Schick, Rutgers University; Amartya Sen, Harvard University; Christopher A. Sims, Unversity of Minnesota; Hal Varian, University of Michigan.

\section{Aims and Scope}

Economics and Philosophy is a semi-annual journal designed to foster collaboration between economists and philosophers and to bridge the increasingly artificial disciplinary boundaries that divide them. Economists more and more acknowledge that their work in both positive and normative economics depends on methodological and ethical commitments that demand philosophical study and justification. Philosophers increasingly insist that philosophy of science must be informed by and tested against studies of current science and of its history, while ethics and political philosophy must depend on what we know about human aims and interests and about the principles, benefits, and drawbacks of different forms of social organization.

Articles in Economics and Philosophy will explore the foundations of economics as both a predictive/explanatory enterprise and a normative one and will examine the relevance of economic techniques, methods and conclusions to philosophical questions in ethics and social theory.

\section{Editorial Office}

Economics and Philosophy, Department of Economics, Fernald House, Williams College, Williamstown, MA 01267, U.S.A.

\section{Publishing, Subscription, and Advertising Offices}

Cambridge University Press, 40 West 20th Street, New York, NY 10011, U.S.A.; or (outside the U.S.A. and Canada) Cambridge University Press, The Edinburgh Building, Shaftesbury Road, Cambridge CB2 2RU, England.

\section{Subscription Information}

Economics and Philosophy is published biannually. Annual subscription rates for Volume 7 (1991): Institutional, US $\$ 58.00$ in the U.S.A. and Canada; UK $£ 37.00$ in the U.K. and Eire; UK £39.00 elsewhere. Individual, US $\$ 29.00$ in the U.S.A. and Canada; UK $£ 18.00$ elsewhere. Prices include postage and insurance.

\section{Copyright 1991 Cambridge University Press}

All nghts reserved. No part of this publication may be reproduced, in any form or by any means, electronic, photocopying or otherwise, without permission in writıng from Cambridge Unıversity Press. Photocopying information for users in the U.S.A.: The Item-Fee Code for this publication $(0266-2671 / 91 \$ 5.00+.00)$ indicates that copying for internal or personal use beyond that permitted by Sec 107 or 108 of the U.S. Copyright Law is authorized for users duly registered with the Copyright Clearance Center (CCC) Transaction Reporting Service, provided that the appropriate remittance of $\$ 5.00$ per artıcle is paid directly to: CCC, 27 Congress Street, Salem, MA 01970. Specific written permissıon must be obtained from Cambridge University Press for all other copying. Contact the ISI Tearsiteet Service, 3501 Market Street, Philadelphia, PA 19104, for single copies of separate articles. 